\title{
1. A critique of political technology
}

\subsection{POLITICAL TECHNOLOGY, GOOD GOVERNANCE AND STATECRAFT}

Political technology refers to the exercise of political power. 'Technology' includes the entirety of practices, norms and principles, forms of knowledge and skills, calculations, strategies and tactics that state actors and institutions use in their operations. 'Political' and 'legal' characterize modalities of how power is exercised. They address an important component of Michel Foucault's multifaceted concept of governmentality. ${ }^{1}$ However, in contrast, political technology stresses statehood as a sphere of activity and intervention for intersecting goals and operative strategies; and it also highlights the importance of law as a form of intervention and basis of authority in the exercise of power. The more common but narrower concept of governmental technology encompasses in its conventional use only the executive and administrative aspects of political technology and emphasizes practice, namely governing itself, whereas political technology also encompasses legislative practices of power as well as private agencies acting in the service of the state.

The technology of governing is not always clearly distinguished from the art of government or statecraft with its rather mixed fortunes. From antiquity to the Enlightenment, political philosophy conceived the art of government mainly as the virtuosity or prudentia required by a ruler. The art had to show in forward-looking and prudent politics and policy. ${ }^{2}$ In

1 Michel Foucault highlights the specific governmental rationale for raising a problem in a certain manner as well as highlighting the governmental practices and technologies that are applied to solve these problems according to this rationale. As with the concept of power, Michel Foucault's concept of 'governmentality' is complex yet underdetermined. Foucault, The Birth of Biopolitics. See also Lemke, 'The Birth of Bio-Politics'.

2 Accordingly, the title of Machiavelli's The Prince was initially translated as On the Statecraft of a Prince. Cf. Foucault, 'Governmentality'. For statecraft as virtuosity, see Müller, 'Erste Vorlesung über König Friedrich II', at 189. For statecraft as prudentia, see Walter Euchner, 'Demokratietheoretische Aspekte der politischen Ideengeschichte'. 
his Social Contract, Rousseau painted a rather positive, idyllic picture of statecraft in a monarchy:

Thus the will of the people, the will of the prince, the public force of the State, and the particular force of the government, all answer to a single motive power; all the springs of the machine are in the same hands, the whole moves towards the same end; there are no conflicting movements to cancel one another, and no kind of constitution can be imagined in which a lesser amount of effort produces a more considerable amount of action. Archimedes, seated quietly on the bank and easily drawing a great vessel afloat, stands to my mind for a skilful monarch, governing vast states from his study, and moving everything while he seems himself unmoved. ${ }^{3}$

Whoever refers to statecraft today may want to stress the difficulty of governing or rather assume a critical or ironic position, but is not likely to have political virtuosity or prudence in mind. ${ }^{4}$ Usually presidents, federal chancellors, cabinet members and so forth are seen as neither artists nor magicians, though they may see themselves that way. ${ }^{5}$ In the political arena, they rather appear as pragmatic jugglers of things possible. Still, the concept of the art of government is experiencing a modest renaissance at present. In this vein, a bold essay recently vindicated 'craftsmanship in questions of government and administration' as a foundation for reconstructing and renewing the welfare state, with the aim of updating the inner relationship of the state, the art of government and the good life. ${ }^{6}$ And the US Department of State went online with its programme of ' 21 st Century Statecraft' 'complementing traditional foreign policy tools with newly innovated and adapted instruments that fully leverage networks, technologies, and demographics of our interconnected world'. ${ }^{7}$

3 Rousseau, 'The Social Contract', Book III, ch. 6.

4 Hillary Clinton was quite serious when she referred to '21st Century Statecraft'. However, the reference to 'Mugabe's art of government' in Zimbabwe has to be taken as bitter irony; while the characterization of German environmental policy as a 'Dadaist art of government' comes with a much lower degree of bitterness.

5 As former British Prime Minister Margaret Thatcher reveals in her self-congratulatory political autobiography: Statecraft: Strategies for a Changing World.

6 Vogel, Die Staatsbedürftigkeit der Gesellschaft, 97 and 99 ff. (with references to Sternberger, 'Das Menschenrecht nach Glück zu streben' and Mulgan, 'Vom Staat und vom Glück').

7 http://www.state.gov/statecraft (23 March 2013), see also The Economic Times, 17 April 2013. 
Moreover, the art of government has for some time now - albeit with a different meaning and lower normative charge - (re)turned to classical semantics and pre-democratic ideas of a good order in the fashionable guise of the concept of good governance. ${ }^{8}$ However, nowadays it often refers to governmental practice in the developmental context. ${ }^{9}$ A brief glance at the respective theoretical and conceptual controversies ${ }^{10}$ indicates that, informed by economics, governance describes the practices and techniques of governing in complex regulatory systems. In contrast to government, governance is meant to encompass non-hierarchical structures of order as well as non-imperative, collaborative and informal state actions in order to better capture the effects such disparate phenomena as globalization, supranational multi-level systems or models of new public management have on domestic administration.

So why introduce the concept of political technology executed by state agencies and agents, given that the state as a form of rule seems to cause more problems than it solves, and since the concept of governance, although still somewhat controversial, is readily available? A number of reasons can be marshalled here: first, the state is familiar as a concept and idea and still around, despite theoretical obituaries. Second, there are indications that 'society is in need of the state' ${ }^{11}$ Even in a socioeconomic environment driven by technological progress and centred around the economy, there is sufficient theoretical reason and empirical evidence to assume that markets, the financial system, the societal division of labour and the distribution of wealth still reckon with and rely on state intervention. Third, I want to demonstrate that the focus on political technology employed by state agencies and agents captures more accurately than the concept of governance the specific constellations between law-rule and the state of exception in pursuing security

8 Explicitly in Meinert, 'Städtische Regierungskunst'; implicitly in UNESCAP, 'What is Good Governance?', which lists eight criteria of good governance, and IMF, Good Governance: The IMF's Role. See also Theobald, Zur Ökonomik des Staates.

9 See e.g. Smith, Good Governance and Development; Noman et al., Good Growth and Governance in Africa.

10 I return to the debate about governance below (Chapter 2). For the different key facets and issues discussed, see the seminal volume by Rosenau and Czempiel (eds.), Governance without Government. A critical overview of governance projects at the global level, which is beyond the scope of this book, is provided by Kennedy, 'The Mystery of Global Governance'; see also id., Global Governance?

11 Vogel, Die Staatsbedürftigkeit der Gesellschaft (supra note 6). 
agendas, like counter-terrorism, fighting 'organized crime' or the selfpreservation of the state. Fourth, the following reflections on the technical aspects of statecraft are meant to help demystify the state and, especially, a view of the state as the epitome of the neutral mechanics of the sovereign art of governing. The concept has therefore a critical function. Fifth, this critique has to prove itself vis-à-vis the concept of security, which has worked and still works as the main rationale for and objective of political technology. With regard to this very objective, my analysis addresses threat scenarios, instruments and rules, as well as methods and strategies of threat prevention together with their particular risks and side effects. In the following, the operative methods and techniques that can be attributed to the state are, hence, narrowly understood as security technology, whose rules and measures, forms of knowledge and practices react to situations of risk that range from the specific to the highly general, in both normal but also emergency situations. ${ }^{12}$

Regimes ${ }^{13}$ under ordinary law-rule or extraordinary emergency law equip the rationale of political technology with its respective meaning and direction in two areas of conflict: the legal prevention of abuse (directed against the arbitrary use of state power) and the prevention of dangers under emergency law (covering siege, war, insurrection, civil war, disaster, political uprising, etc.). In an ideal-typical contrast, regular law and emergency law mark and structure the areas, in which the security dispositive requires or engenders its specific political technology - depending on whether the task is to regulate, steer, control, inform or discipline under regular law or to monitor, subjugate, put down, pacify, detain or coerce under emergency law.

Law-rule - covering the varieties of the rule of law, Rechtsstaat and état de droit - and the state of exception, not only as its dark side and nemesis but also its twin brother, are at the heart of the following considerations. They are introduced here as contrasting perspectives for the analysis of fuzzy and topical phenomena, such as the "preventive state' or 'surveillance state', counter-terrorism and civil sacrifice. They

12 My considerations of political technology refer to the sphere, institutions and agents of domestic and external security but not to the field of social security or other political areas, like financial or fiscal security.

13 In the following, I use the term regime either to mark the specific and fundamental characteristics of a form of political rule (e.g. authoritarian or democratic regimes) or the ensembles of norms, principles, procedures of decision-making and practices that constitute institutions in particular policy areas (e.g. the human rights regime). 
play a crucial role in the discourse on security for both the justification and critique of extreme measures, such as violence and the treatment of 'dangerous persons' as enemies under criminal law.

\subsection{POLITICAL TECHNOLOGY AS MINDSET}

\section{The Mentality of Engineers}

Political technology is defined by an attitude or mindset and a method. The mindset of political technicians is meant to capture the way engineers think and act in political contexts. The engineers of political technology show, therefore, primarily a technical interest in, and a utilitarian and instrumentalist understanding of, the exercise of power, both of which in general allow for a merely tactical relationship to law. ${ }^{14}$ Such instrumentalism is reflected in current notions of statecraft as the efficient and up-to-date use of power. ${ }^{15}$

Based on the claim of neutrality and on the legitimacy of expertise, their actions are pragmatically geared towards what is technically feasible. According to their ideology, success is measured by the effective functioning of institutions and the efficient implementation of policies; it can be assessed via the discrepancy between defined and achieved goals as well as the ratio of costs and benefits of, for instance, sweeping surveillance measures, brutal interrogation methods or the military intervention in Iraq. ${ }^{16}$ Of course, practice shows that the engineers of and technical experts in governmental and administrative techniques often try to avoid the legal evaluation and monitoring of their actions, despite their focus on functionality and success. ${ }^{17}$ They try to be as little bothered as possible by institutional or legal constraints, like civil rights or the test of

14 Jürgen Habermas refers to the construction of social order and not to political technology, when he states in Theory and Practice, 43: 'The engineers of the correct order can disregard the categories of ethical social intercourse and confine themselves to the construction of conditions under which human beings, just like objects within nature, will necessarily behave in a calculable manner.' For dictatorship as the approach to the state of exception in political technology, which corresponds to the 'technical interest of an engineer in producing a thing', see Schmitt, Die Diktatur, $8 \mathrm{ff}$.

15 E.g. the US Department of State's '21st Century Statecraft' programme and Margaret Thatcher's revelations (id., Statecraft).

16 This frame of mind is illustrated by Posner, The Perils of Global Legalism.

17 For the numerous EU-financed legislative projects in the post-socialist states, appropriate investigative research into effectiveness is still lacking. 
proportionality, which might impinge on their freedom to decide and act. Unlike public officials who base their mission on a legal or political mandate, if they have not already chosen to mandate themselves, the public official as engineer tends to derive his or her mandate from a superior good, their supposedly superior knowledge and technical expertise.

Charismatic or authoritarian self-mandating and openly elitist mandates on the basis of a higher good or goal (like a revolution or the preservation of national unity) or superior knowledge (like the privileged insight into the historical 'laws' of socialist development) necessarily fade into the background in functioning democracies. In the national and, even more so, the international context, the mentality of political technicians has invaded politics and has come to dominate the various fields of policy. ${ }^{18}$ Unlike experts, the protagonists of political technology are neither outsiders nor limited to generally advisory, subaltern roles and functions. ${ }^{19}$

In critical situations, politicians, no matter in what kind of role they appear, tend to shift to an engineering mindset and basically privilege technical rules and standards that apply to the problem or policy they have to cope with, over the principles and standards of law-rule and democracy. In these circumstances, legal concerns and constraints become a secondary priority at best: they are heeded, if they establish weak or no checks on political-technological considerations or can be utilized for legitimizing purposes. To the extent that law is meant to protect individual liberties against state interventions and to question inherent 'necessities', experts usually have a rather ambivalent, tactical take on law. And the ideology and operative implications of a 'lawful government', as is demonstrated by the 'war on terror' or the recent management of the Euro crisis, mutate on the quiet to a style of governing that deviates from democratic law-rule to political technology

Security policy-makers show a similar lack of interest in proving the effectiveness of their measures, when they routinely demand the extension of their competences, especially when it comes to the fight against 'organized crime' or terrorism (Hoffmann-Riem, 'Das Bundesverfassungsgericht als Garant von Rechtsstaatlichkeit', at 560).

18 The problematic nature of a politics of expertise in the international context is discussed by Kennedy, 'Challenging Expert Rule'.

19 For the distinction between the various types of political-social engineers the expert, the technocrat and the political technician - see Frankenberg, 'Die europäische Union der Staatstechniker und Experten'. 
carried out by state technicians who tend to treat the legislator and the law as hindrances in the way of Pareto-optimal problem solutions.

\subsection{POLITICAL TECHNOLOGY AS METHOD}

The mindset of political engineering translates into methods of political technology. In general, the term 'method of political technology' encompasses knowledge, practices, tactics, strategies and objectives. These operative aspects are shaped by the acting authorities, their competences, the regime of rules and procedures they have to operate in, their calculations and forms of knowledge as well as their overall characteristic - primarily legislative or executive - style. These methods I distinguish, if only for analytical reasons and ideal-typically, from legal techniques before I introduce four paradigms of political technology.

\section{In the Shadow of Hierarchy}

While standard legal techniques of governing operate, as a rule, within hierarchical structures, methods of political technology do not or, at best, remain in the shadow of hierarchy. As regards their general features, methods of political technology differ from legally formed, framed and legitimized techniques, first, in their informality, second, in their indirect impact, and third, and most importantly, in the imperatives of the underlying political (security) project they pursue.

First, conventionally, the predicates 'imperative' and 'formal' refer to the particular characteristics of the legal technique illustrated by parliamentary statutes, ordinances, decrees, administrative acts, etc. In regimes of self-government such decisions place decision-makers in a framework of separated powers and parliamentary, judicial or administrative controls. Dressed in the standard practices of law, the actors - legislators, presidents, administrators, courts, etc. - operate in a (more or less) hierarchically structured and horizontally interconnected system of competences and try to resolve conflicts through imperative, legally framed steering.

In recent times, the set of governmental techniques and practices has also included cooperative and more flexible methods.

With the advent of governance techniques, the world of formalimperative legal commands and exercise of power has receded or rather shifted visibly to political technology. Power is exercised flexibly and informally not only by public/state authorities but also by private agencies (not always) specially empowered by law. The various new and 
not so new forms of cooperation are illustrated by public-private partnerships, administrative agreements, 'deals' under criminal law and court settlements. However, all these cooperative forms remain in the 'shadow of hierarchy', ${ }^{20}$ because it is always possible to fall back on the imperative arsenal of steering instruments in case informal cooperation fails.

The coordinates of knowledge informing and guiding political decisions shift from power/law to power/expertise. ${ }^{21}$ While government had always relied on knowledge, through expertise it receives a special mandate and mostly informal, political legitimation. This shift has become dramatic since the advent and rapid deployment of information technology. All by itself the informal style of governing, based on expertise rather than officially generated and, according to the ideal of parliamentarism, publicly debated knowledge, reveals an affinity between governance and political technology, which is discussed below as one of the ambivalences of the liberal paradigm.

Second, no matter whether it regulates, steers, prohibits, permits, informs, coerces or subjugates, legal technology - as method - is generally and ideal-typically geared towards directly intervening in the social sphere and economy or regulating individual behaviour. For this purpose, binding legislative or administrative decisions and court judgments coordinate actions and events and their consequences, if necessary with the help of force. These authoritative decisions concern the interaction between authorities and actors, which either exercise authority or, as societal actors, are involved in or affected by them. Also, conventional methods have basically and ideal-typically relied on regulation based on 'conditional programmes', i.e. the legal elements of rules authorizing governmental or police action or court sanctions for specific incidences and, respectively, individual cases.

Legal technology has never exclusively been constituted by strictly formalized, directly targeted regulations. It has always comprised provisions leaning towards political technology by granting discretion to administrative agencies and even courts due to indeterminate concepts and blanket clauses which have made the structure of conditional programmes porous, opening them up to consideration of political purposes.

20 This metaphor I borrow from Scharpf, Games Real Actors Play, 197.

21 See Kennedy, 'Challenging Expert Rule' and Frankenberg, 'Die europäische Union der Staatstechniker und Experten'. 
In recent years, however, the standard modalities of legal technology have shifted considerably from the direct regulation of behaviour to the indirect disciplining of social processes. Information technology permits the monitoring of the movement of individuals and groups, the screening of social communication and economic transactions, and surveillance not only of public spaces. 'Dummy' clauses authorize the sweeping collection and processing of data; and statutes authorizing operative police action contain a variety of not only preventive but pre-emptive screening and surveillance measures. ${ }^{22}$ They testify, if not to a paradigmatic shift, to the rapid advance of relatively new forms of indirect steering mechanisms to generate knowledge from military, secret service, police and also private sources. This new knowledge production is not only run by experts in information technology, it is also only very loosely connected with legal forms and legal constraints, thus opening up spaces for tactical manoeuvres, such as cooperation and data exchange between the police and secret services as well as the symbiosis of the military and commercial rationality in the collection, aggregation, exchange and use of data. Therefore, this ensemble of post-1984 measures qualifies as political technology.

The semantic and theoretical shift from government to governance captures some aspects of the general features of and the transition to a technology with a political DNA. With this shift the overall perspective changes from formal to informal rules, from direct to indirect modes of operation involving both state institutions and agents as well as private actors - companies, networks and civil society associations - as in principle equal partners in the decision-making process. ${ }^{23}$ The governance perspective includes the whole variety of collective actors, their connections and relationships and the diversity of new instruments of (self-)steering within the activating nation-state and in complex multilevel systems, like the European Union, ${ }^{24}$ and may help elucidate the concept and methods of political technology.

22 The shift from prevention to pre-emptive measure or 'hyper-prevention' will be discussed in the context of the two crises of law-rule triggered by national and transnational terrorism (Chapters 5 and 6).

23 From the plethora of literature on governance, see Mayntz, 'Governance Theory als fortentwickelte Steuerungstheorie'; Arthur Benz, 'Nationalstaat'; and OECD, Online-Verwaltungslexikon, http://olev.de; Report on European Governance (2003-04), SEC (2004) 1153, 22 September 2004.

24 In contrast to government, governance seems to be conceptually geared towards the combination of hierarchy and competition, of command and negotiation structures, of bureaucracy and networks, of formal and informal actions. 
Third, from the variety of political projects that can be and are being pursued with the means and methods of political technology, I choose and focus on security because it has pervaded and come to dominate the arenas and discourses of politics, economics and law. More than any other policy topic, the varieties of security - or: the shifts and rifts of the security dispositiff 25 - testify to the transformation of the methods of governmental techniques and the tension between the normal and exceptional situation. In different security regimes, operative techniques applied by the state change their shape and modus operandi significantly. Threats to the safety of the public or the political regime - or at least the official political, military or police perception of them - raise issues that are meant to be addressed by the use of new technologies, especially information technology, and the appropriate expertise. Furthermore, also in the area of security policy questions arise of how, with what methods and instruments, to resolve the conflicts and problems of interdependence that emerge at the territorial, social and functional boundaries of the state as institution. This becomes even more pertinent, since they are accompanied by a loss of certainty 26 and entail, seen from the perspective of the actors, a significant need for uncontrolled, unofficial and informal coordination. ${ }^{27}$

By contrasting law-rule and extraordinary rule beyond the law, i.e. the state of exception, different paradigms of political-technological methods can be teased out. The key criteria for the following distinction and attempt at model building are: first, whether given governmental techniques operate within the context of a predetermined difference between a normal and exceptional situation; second, and relatedly, whether and to what extent they are hemmed in by external legal rules, or whether they follow the rules of their own logic and technical code; and third, which strategic objectives the technicians are required to pursue by the changing topos of security.

The modelling that follows does not aim at writing a history of the state or governmental techniques and their inventors. Following Max

25 Following Foucault, 'dispositif' denotes primarily the heterogeneous ensemble of discourses, institutions, regulatory decisions, law, administrative measures, scientific statements, normative (moral, ethical, etc.) positions. See Foucault, 'The Confessions of the Flesh'.

26 Baumann, Modernity and Ambivalence.

27 Cf., although not limited to the field of public security, Mayntz, 'Verwaltungsreform und gesellschaftlicher Wandel', and Benz, 'Nationalstaat', 343. 
Weber's ideal-types, ${ }^{28}$ my aim is rather to emphasize and bundle diffuse and discrete phenomena for heuristic purposes. And I pursue a twofold objective: first, to highlight the different, specific, ideal-typical rationale of the techniques applied; and, second, to emphasize the effect of this rationale on the relationship between the holders and users of state power and their addressees.

\section{The 'Method Machiavelli'}

Political technology as a bundle of specific techniques for executing power is here introduced as method Machiavelli - not because it was invented or exclusively designed by the author of The Prince ${ }^{29}$ but since it can arguably be related to what Michel Foucault called an 'abominable text'. ${ }^{30}$ Under the guiding principle of the person of the ruler as the linchpin of 'reason of state', it functions as a technology for the acquisition and defence of sovereign power unhampered by moral and legal constraints. Neither concerned with the distinction between normalcy and emergency and the corresponding separation of competences nor hindered by legal rules, ethical principles or duties of virtue, such a political technology is tailored to the prince and therefore focuses on the acquisition and conservation of his power, as in the teachings of the Sophists. According to Machiavelli, political power in the conventional sense, as the control over territory and its resident population, might not be acquired casually by birth but through negotiation or force and is exercised at the will of its owner free of formal or normative constraints: 'There is no fundamental, essential, natural and juridical connection between the prince and his principality.' 31

The difference between princely authority in a legally normal and an exceptional situation cannot reveal itself in the context of Machiavelli's empirical political sociology and psychology. Only by contrasting the Republic and (Roman) dictatorship is Machiavelli able to draw the

28 Weber, Economy and Society, especially 19-22. Here, method does not mean scientific method in the modern sense; the methods outlined in the following are therefore really presented as ideal-types and should not be misconstrued as a scientific product of their respective namesake.

29 Machiavelli, The Prince. See also id., The Discourses, ed. Bernard Crick (London: Penguin, 1984). Cf. for this and the following, Skinner, Machiavelli; Kersting, Niccolò Machiavelli and Münkler, 'Machiavelli, Niccolò'.

30 Foucault, 'Security, Territory, Population', 73-9.

31 Michel Foucault, Security, Territory, Population: Lectures at the Collège de France, 1977-78, 93. 
contours of a 'useful', because temporary, state of exception meant to resolve a crisis quickly. ${ }^{32}$

Shaped by the situation and political climate in the Italian Republics, The Prince reads like a sober, sometimes cynical instruction manual for establishing and stabilizing princely families and state structures. Its author advises the ruler to always do what is required to consolidate his power position and to protect his principality. Neither charisma nor ethical leadership is required when dealing with internal and external enemies, but depending on the circumstances the prince has to act like a lion or a fox (Lysander) $)^{33}$ - cruelty, deceit, fraud, corruption, treason, but also care or incentives, such as rewards or a prospective office, need to be applied. Machiavelli advises the prince to utilize his strategic and tactical skills, which does not equate to the use of statecraft in the sense of a virtuous, wise and economic steering of individuals, goods and wealth.

The Machiavellian scheme, dominated by technicity, subverts the clear distinction between regular order and exception and allows for a variety of authoritarian and even dictatorial techniques, which foreshadow the informality of current techniques of governing. ${ }^{34}$ Therefore the Machiavellian technology of politics has not died with the demise of its namesake or the Italian republics. Rather, its method and mentality of self-mandating, which refers to sovereignty for use by the sovereign, transcends their original context. Due to its strict focus on the ruler, its formlessness and normative abstinence, the method Machiavelli meets the needs of the leadership in authoritarian regimes of all kinds, mainly concerned with maintaining their power, like the regimes of Vladimir Putin and Alexander Lukashenka, both marked by a scheme of power preservation without even a hint of occasional virtue. Not only can the method Machiavelli still be observed in its traditional field of application - politics: imperial presidents use it regularly, ${ }^{35}$ while less imperial democratic leaders may fall back on it in times of crisis, such as the crisis of the Euro, or at authoritarian moments when preservation of power calls for the suspension or circumvention of democratic law-rule.

However, in constitutional states, the Machiavellian style meets with constraints by the constitution. This is why Machiavellian shifts from law to an 'occasional virtue' or the dictates of raw power require a pseudodemocratic or pseudo-legalist masquerade. Such camouflage tends to

32 Machiavelli, The Discourses, chs. XXXIV-XXXV. Cf. Rossiter, Constitutional Dictatorship, 301 and Schmitt, Die Diktatur, $7 \mathrm{ff}$.

33 Cf. Stolleis, 'Löwe und Fuchs'.

34 See McCormick, 'Addressing the Political Exception'.

35 Prempeh, 'Presidential Power in Comparative Perspective'. 
borrow from the semantics or the arsenal of the state of exception. ${ }^{36}$ No masquerade is warranted if the general public relishes rather than objects to the chief executive officer's repeated abuses and breaches of law for the preservation of his power. ${ }^{37}$

More commonly, the Machiavellian method shies away from the democratic and legal life-world and retreats to areas with no or less pronounced legal rules and democratic structures. To (at least semipolitical) areas, that is, where the exercise of power means 'to do whatever it takes'38 with hardly any (legal) restraint and outside control. Private corporations and the European Central Bank qualify as zones for Machiavellian moments and methods; furthermore political parties and, in particular, the World Soccer Association (FIFA), whose presidents have gone out of their way to gain the reputation that they will do 'whatever it takes', including using Mafia methods, to gain and stay in power. ${ }^{39}$

\section{The 'Method Hobbes'}

The method Hobbes is aligned with more complexity, normatively speaking. Its foundations and various facets can in the main be traced back to the Elements of Law and the Leviathan. ${ }^{40}$ In these politicophilosophical studies, Thomas Hobbes designs a 'physics' of power against a backdrop of the chaotic context of England torn by religious wars and power struggles. Based on the discrepancy between the state of nature and the social condition, he comes up with a concept of abstract sovereignty and constructs the state as a peace machine. Against the tradition of absolutism, which by then dominated political philosophy, he bases the power of the sovereign on a network of reciprocal contracts in

36 The freehand suspension of the German Nuclear Power Act in 2011, which was at the time only a couple of months old, by the government of Chancellor Angela Merkel can be characterized as a Machiavellian emergency measure dictated by the logic of power preservation after the disaster of Fukujima.

37 As happened, for example, in Italy during the extended populist sultanate of Silvio Berlusconi; see Sartori, Il Sultanato.

38 'Within our mandate, the ECB (European Central Bank) is ready to do whatever it takes to preserve the euro.' Mario Draghi, Speech at the Global Investment Conference, London, 26 July 2012.

39 E.g. Jennings, Foul! The Secret World of FIFA; Kistner, FIFA-Mafia.

40 Hobbes, Elements of Law Natural and Politic; id., Leviathan; and id., De Cive. 
favour of an independent third party. ${ }^{41}$ In his Leviathan, Hobbes binds this third party, the holder of sovereign authority, to a central political goal: the protection of life to ensure peaceful coexistence. In this way, he attributes for the first time the essential aspects of a security calculation to a political technology, which is concentrated in the hands of the sovereign, oriented towards the executive and imperative; while the security calculation itself is linked to the justification of absolute power. At the same time, Hobbes shifts the rationale for the state from the Machiavellian interest of the prince 'in himself' to the robust interests of the estates and the utility maximizers in the bourgeois competitive society, which emerged before his very eyes.

In the Elements of Law, Hobbes specifies the way sovereign power is exercised over the subjects regarding any conflict of life in society. He explicitly regards state technology as the 'art of government' ${ }^{42}$ While the theory of sovereignty is the basis for the supreme duty of the ruler to preserve state and society, to protect them from relapsing into the anarchic state of nature, to enact general laws for this purpose and to enforce them universally, the art of government manifests itself in the 'good government of the people' for the mutual benefit of sovereign and subjects:

And as the art and duty of the sovereigns consists in the same acts, so also doth their profit. For the end of art is profit; and governing to the profit of the subjects, is governing to the profit of the sovereign. (...) Salus populi suprema lex; by which must be understood, not the mere preservation of their lives, but generally their benefit and good. ${ }^{43}$

Thus, Hobbes bases his method of state technology on a double strategy, namely to ensure both the preservation of the state and the safety of the people, which coincides with 'salus populi' in his Leviathan as well as to promote, without obligation, the common good (in the Elements of Law). ${ }^{44}$

In light of the Hobbesian theory of sovereignty, the outlines of a bisected rule of law begin to emerge. With the focus on the prevention of

41 For a detailed account of this often overlooked innovation in Hobbes' work, see Hampton, Hobbes and the Social Contract Tradition, 97-113 and 114-29; Skinner, Freiheit und Pflicht.

42 For the following, cf. also Bohlender, 'Metamorphosen des Gemeinwohls', $249 \mathrm{ff}$.

43 Hobbes, Elements of Law, part II, ch. 9.

44 Hobbes, Leviathan, ch. 30. Ferejohn and Pasquino ('The Law of the Exception') focus on safety of the people (p. 224). 
threats from within and from the outside, the techniques employed by the state turn out to be security technology. Although sovereign rule, unless legitimized by conquest, has its origins in contractual law, the political order guaranteed by the Leviathan entails neither a re-connection to the contracting parties nor a separation of powers. Hobbes rejects both expressly. Due to his fear of possible dangers that threaten the political order and the resulting organization of safety, he consequently arrives at a conception of state power as indivisible: legislation, taxation and jurisdiction, the supreme command of the armed forces and the decision on war and peace - the 'sword of war' and the 'sword of justice' 45 - are to remain in the hands of the sovereign. After all, the ruler has obligations imposed on him by natural and divine rights. However, in the absence of a higher authority, these obligations are not enforceable. In today's terminology, they have rather the character of 'soft law' in the sense of a non-binding voluntary commitment. Derived from the theory of sovereignty, the rationale of obedience ('the purpose of obedience is protection' $)^{46}$ contradicts the substantive rationale of the art of government (salus populi) only at first glance. For on the basis of the asymmetrical relationship between rulers and ruled, the logic of care does not bind the methods and instruments of political technology; rather it remains itself tied 'to the preservation and enhancement of state power' ${ }^{47}$

Hobbes designs the relationship between the sovereign and its subjects as a general relationship of subordination constituted by reciprocal, third-party beneficiary contracts. The right to sovereignty and the fear 'that disposeth to rebellion is pretence of right' 48 block his way to an even moderately substantial concept of the constitutional state. Only with their agreement that institutes the sovereign, do the individual members of a society as subjects gain membership of the state and its protection. In return, they give up a significant portion of their freedom and their right to everything, including the right to resist, in exchange for their safety, as long as the Leviathan is able to fulfil its protective function. They cannot complain about 'legal violations' committed by or attributed to the sovereign, since they have authorized him by contract to be the source of law: volenti non fit iniuria. ${ }^{49}$ In the shadow of this absolute

45 Hobbes, Elements of Law, part II, ch. 1 (7-12) and ch. 8, where Hobbes refers to Bodin's Six Books of the Commonwealth, Book II, ch. 1.

46 For the purpose of obedience, see Hobbes, Leviathan, ch. 21.

47 Bohlender, 'Metamorphosen des Gemeinwohls', 251.

48 Hobbes, Elements of Law, part II, ch. 8.

49 Ibid., ch. 2 (3) and ch. 5 (2); id., Leviathan, ch. 21. 
power over life and death, they are left with the residual freedom to do what has not been regulated by the ruler and to refuse obedience, if necessary. In the area of what is regulated, civil laws inevitably link the ears of the subjects to the lips of sovereign authority. ${ }^{50}$

If one leaves aside the exceptional situation of the state of nature, the Hobbesian fear-driven theory of sovereignty and conflict lacks the conceptual space for a worldly state of exception and to conceptualize the latter as an alternative to the norm. Nevertheless, the superior purpose of security suggests that Hobbes differentiates in his concept of political technology between 'the greatest inconvenience that can happen to a commonwealth', which is war and civil war, i.e. the ever-looming relapse into a state of nature as exceptional situation, on the one hand, and everyday conflicts triggered by the 'right of self-help' on the other hand. ${ }^{51}$ The final chapter of the Elements of Law in particular can be read as a manual for the sovereign to prevent revolt:

For maintaining of peace at home, there be so many things necessarily to be considered, and taken order in, as there be several causes concurring to sedition. ${ }^{52}$

Among other things, Hobbes considers it necessary in order to secure domestic peace 'to set out to every subject his propriety, and distinct lands and goods', 'to divide the burthens, and charge of the commonwealth proportionately' and to exercise 'due ... justice' through 'the right performance of their duties, on the parts of those, who are the magistrates'. He also recommends taking measures in order to impose penalties so that 'there ought to be some means for the keeping under of those that are disposed to rebellion by ambition'.

The characteristics of the imperative and executive political technology outlined in the Elements of Law and the Leviathan have survived its author, work and original context even more successfully than in the case of Machiavelli. For Hobbes, the father of security technology, it was clear that one's neighbour could not be trusted: he might be a supporter of Cromwell or a royalist, a Catholic or Puritan, an aristocrat or a Leveller.

50 Hobbes, Leviathan, ch. 21. Hobbes mentions as examples of this freedom: 'the liberty to buy, and sell, and otherwise contract with one another; to choose their own abode, their own diet, their own trade of life, and institute their children as they themselves think fit; and the like'.

51 Hobbes, Elements of Law, part 2, chs. 5, 8 and 10.

52 Ibid., part 2, ch. 9. 
Even in consolidated constitutional democracies, most conservative political philosophers and security policy-makers are prone to such mistrust. They constantly update the Hobbesian question of how political rule can be protected from dangerous individuals (Gefährder), harmful elements and exuberant, untamed initiatives of the citizenry. In this way, Hobbes is still regarded as the godfather of the preventive security state a reading that somewhat unfairly reduces his work to the concept of the security state.

In the subsequent chapters, I will show that even critical situations for internal and external security, which rank below the threshold of a 'major crisis' or the state of emergency, offer the opportunity to apply measures of the method Hobbes and to connect it with other methods of political technology.

\section{The 'Method Locke'}

The method Locke as legal technology introduces elements of the liberal paradigm which at first glance could not be more different from the Hobbesian security state with its emphasis on the protection of natural rights. Nevertheless, the protection of property, liberty and security of the individual as well as the somewhat hidden protection of the 'body politic' is down to the purpose of security:

But because no political society can be, nor subsist, without having in itself the power to preserve the property, and in order thereunto punish the offences of all those of that society, there, and there only, is political society where every one of the members hath quitted this natural power, resigned it up into the hands of the community in all cases that exclude him not from appealing for protection to the law established by it..$^{53}$

Security does not vanish as topos; rather, its elements are only re-organized. Against the backdrop of the Glorious Revolution of 1688-9, John Locke maintained after his liberal turn that political rule is constituted by social contract. His position was not based on the reciprocal waiver of rights by the subjects in order to secure internal and external peace. Rather, from Locke onwards, the mutual social contract establishes a legislature as supreme authority and thereby institutionalizes majority rule. Absolutist sovereignty is replaced by parliamentary sovereignty, which programmes the actions of the executive with the help of

53 Locke, Two Treatises of Government, 'Second Treatise', ch. 7, § 87 (emphasis added). 
laws and finds its limits in the fundamental, natural rights to property and personal freedom. In the field of operative techniques used by the agencies and agents of the state, this legislative method pushes executive thinking into the background and sets out to establish legal restraints on the security-driven power engineer in the form of basic rights and constitutional principles (proportionality; determinacy). While both are rather loose and indeterminate concepts, they can still be reviewed by the courts.

In contrast to the tradition founded by Hobbes, the philosophical protagonists $^{54}$ of liberal techniques of governing shift their attention, when it comes to the prevention of dangers, from the potentially rebellious citizenry to potentially arbitrary and despotic state power and its incursion into the sphere of property and liberty. In the name of the security interests of a property-owning, bourgeois, male society, ${ }^{55}$ they vie for the institutional design of law-rule that places, on the one hand, limits on the exercise of freedom and ensures, on the other hand, a 'limited and lawful government' basing every exercise of power on a relationship of trust (Locke) or binding it to a contract that establishes rule and authorizes it (Rousseau, Sieyès, Kant) within a system of the separation of powers or checks and balances: ${ }^{56}$

[T] hat both the people may know their duty, and be safe and secure within the limits of the law, and the rulers, too, kept within their due bounds [...].57

In Locke's and other authors' work, varieties of the liberal paradigm replace the central authority with law in the guise of general law that

54 Apart from Locke, Two Treatises on Government, 'Second Treatise', one should also mention the following classics: Montesquieu, The Spirit of the Laws; Kant, The Metaphysics of Morals; Sieyès, Qu'est-ce que le tiers-état?; von Humboldt, Ideen zu einem Versuch, die Grenzen der Wirksamkeit des Staates zu bestimmen and Mill, On Liberty. Cf. Boucher and Kelly, The Social Contract from Hobbes to Rawls and Kersting, Die politische Philosophie des Gesellschaftsvertrages.

55 For a detailed and critical analysis see Neumann, The Rule of Law. Cf. Holdsworth, History of English Law II, 647 ff.; Macpherson, The Political Theory of Possessive Individualism: Hobbes to Locke. For the argument against reducing Locke to such an account of possessive individualism, see Tully, $A$ Discourse on Property. Also in this vein, see Pateman, The Sexual Contract.

56 Locke's notion of the separation of powers remains vague, while Montesquieu, Kant and Sieyès provide more concrete notions. Today, one can find complex systems of the horizontal and vertical separation of state powers and the checks and balances between them in numerous constitutional orders.

57 Locke, Two Treatises of Government, 'Second Treatise', ch. 11, § 137. 
provides, if necessary, for direct interventions in social processes and direct regulation of individual behaviour. In the contractualist context, law-rule is meant to guarantee the normalcy of lawful government (Locke). For the first time, the liberal paradigm highlights the contrast between an ordinary, legally regulated state of freedom and an exceptional state of unconstrained, sovereign arbitrary use of power (relegated to the prerogative). In this way, the power of the ruler fades into the background, while it was still visible in Hobbes' account. As legal order, the system of general laws is given the task of generating normative normalcy. In the later stages of the liberal paradigm, the problematic relationship between norms and validity vis-à-vis facts and effectiveness is addressed in formulas like the 'normative force of the factual' (Georg Jellinek) or 'the very real force of the counterfactual' (Jürgen Habermas). 58

With this construction of a state of normal law or later democratic law-rule, the legislative style assumes a guiding role. In the liberal imagination and ideology, law-rule safeguards the transition from the personal to the impersonal exercise of power by untying the bond of personal loyalty to the monarch and turning it into obedience to law. Thus, laws are imagined to control, if not eliminate, the subjective factor of political rule - authoritarian arbitrariness. This very imagination is expressed by the catchy and brilliant formula 'government of laws and not of men' in the Anglo-American constitutional tradition. ${ }^{59}$ As foil for the depiction of abuses of state power, the rule of law, constitutional state, Rechtsstaat and état de droit refer to both the legal form manifest in law and a corresponding, legally bound and normal exercise of political power. ${ }^{6}$ At the same time, the underlying security agenda focuses political technology on the direct control of behaviour and direct interventions in the socio-economic sphere in the standard form of legal statutes, administrative acts and so forth.

There is a dark side to this paradigm, though: the prerogative of the monarch. On the quiet it transforms the legal techniques of governing into political technology, which is still claimed to be legal. For Locke, the prerogative - the untamed legacy of monarchical despotism - remains

58 Heller, Staatslehre, 251; Jellinek, Allgemeine Staatslehre, 329-30 and Habermas, The Philosophical Discourse of Modernity, 206.

59 The formula has its origins in Aristotle's work and in Harrington's The Commonwealth of Oceana. Cf. Michelman, 'Law's Republic', at 1502.

60 For a detailed and differentiated account of the respective conceptual history, cf. Heuschling, État de droit Rechtsstaat Rule of Law. 
in place, albeit not as the centrepiece of the liberal narrative. ${ }^{61}$ In his design of the liberal paradigm he also recognizes martial law and executive powers as explicit emergency powers. They appear as deviations from regular law - or more precisely, as exceptions to the law - and indicate the illiberalism woven into the fabric of the liberal paradigm and its political rationale. In the course of historical development, variants of the method Locke emerged and included additional exceptional situations that lie outside of the legal framework or transgress its borders. ${ }^{62}$ In the constitutional discourse of the 19th century, war was replaced by the prototypical state of siege ${ }^{63}$ and, informed by the trauma of the Jacobins, political uprisings took centre stage in the imagination of the extraordinary. Finally, in the 20th century the state of exception (and later: emergency) operates as an overarching term for different forms of extraordinary situations of crisis brought about by war, siege, turmoil and disaster. The varieties of the extraordinary raise the question, addressed below, of whether these extreme situations of crisis can be typified, legalized and dealt with according to the ordinary legal pattern of liberal standardization, even though they lie outside of the legal framework.

\section{The 'Method Foucault'}

The method Foucault offers a lateral account of the previously introduced, historicized and ideal-typical methods of political technology. It opens a new and critical perspective on both the method Hobbes and the method Locke as well as on the Machiavellian and non-Machiavellian techniques of exercising power and their underlying threat perceptions and security conceptions. This perspective breaks with the tradition of narratives that justify power and legitimize authority by limiting its scope and exercise. Instead, the strategies and mechanisms of power are analysed without any obvious (or at least: a priori) normative intention. Michel Foucault is not interested in legitimizing but in examining and criticizing the modalities and strategies for the exercise and operation of

61 See Locke, Two Treatises of Government, 'Second Treatise', § 159; for a concise analysis see Loughlin, Foundations of Public Law, 383-7; Dunn, The Political Thought of John Locke, 150 and Pasquino, 'Locke on King's Prerogative', 201.

62 Chapters 3 and 4 will deal in detail with these exemptions from the normativity of the normal state.

63 For a detailed and broad account, see Boldt, Rechtsstaat und Ausnahmezustand. 
power. ${ }^{64} \mathrm{He}$ brings to the fore the modern version of the Hobbesian paradigm which he detects in the liberal paradigm of governmental technology - the illiberal security paternalism - designed with quite practical-legitimizing intent by liberal political philosophy.

Foucault concedes that the Hobbesian theory of the sovereign state and its corresponding political technology appropriately portrays the everyday experience of political domination in feudal societies and roughly also in the post-feudal society the author of the Leviathan was confronted with. The manner in which power was exercised in absolutist times could rightly be captured in the dualism sovereign/subject with regard to its expressions and functions. In contrast to the Hobbesian security dispositive, ${ }^{65}$ a new power mechanism emerges in the 17th and 18th centuries; according to Foucault, it seeks to extract time and labour out of bodies rather than out of goods and wealth:

[T]he body is also directly involved in a political field; power relations have an immediate hold upon it; they invest it, mark it, train it, torture it, force it to carry out tasks, to perform ceremonies, to emit signs. ${ }^{66}$

And these power relations force it, in particular, to emit signs of obedient functioning. Typically, for the method Foucault, this new mechanism is exercised through continued monitoring, control and registration as well as discontinuously via the tax system and recurring obligations to pay charges and provide services. ${ }^{67}$ Whereas Hobbes legitimizes the position of the sovereign and the techniques of the ruler/Leviathan to preserve peace, after having become free of legal interference following the completion of the contract, and whereas the Lockean focus is directed towards taming the monarch and limiting civil society's exercise of liberty, the method Foucault outlines the ensemble of discursive and non-discursive disciplinary techniques and practices of power. Thus, the unitary conception of sovereignty dissolves into various manifestations of 'disciplinary power'. ${ }^{68}$

64 For the following, see Foucault, Discipline and Punish and id., The Birth of the Clinic.

65 Following Foucault, I understand 'dispositive' as the heterogeneous ensemble of discourses and institutions, legislative rules and administrative measures, (legal) scientific statements and philosophical considerations. Foucault, Dispositive der Macht; Deleuze, 'Was ist ein Dispositiv?'

66 Foucault, Discipline and Punish, 25.

67 Foucault, Society must be Defended, 36.

68 For this and the following, see especially the Lecture of 14 January 1976 (Foucault, Society must be Defended, 36 ff.). 
From Foucault's perspective, the Hobbesian concept of ultimate authority emerges with the 'self-exemption of the sovereign', 69 who does not act as a contractual partner but emerges as a unifying effect triggered by the mutual authorization of 'frightened subjects' ${ }^{70}$ With this introduction, Foucault distances himself from both the Hobbesian and postHobbesian concepts of legal and political philosophy in Western societies, which revolve at the beginning around royal power, later around its functional equivalent, the sovereign state, and finally around the rule of law.

With his view of the techniques of disciplinary power and later of biopolitics, Foucault rejects not only the absolutist monarch as the central person and living body of sovereignty, but also the liberal obsession with legitimacy, typical of the method Locke, and the resulting theoretical focus on how to justify and limit power - and authorize its exercise. This focus displaces actual rule and its consequences by its occupation with the juridical and, we might add here, dressing political technology up as a set of legal techniques.

Rather than looking at the head of state (Hobbes) or the natural rights of the propertied class (Locke), Foucault assumes the perspective of the subjugated in order to reveal the 'fact of domination' in their secret and brutal aspects. He intends to expose the law, which generates relations of domination and does not only serve them as a tool, as is suggested in the method Locke. This perspective highlights how the life of those under domination and control is standardized and made subject to authoritative regulations following the security rationale of disciplinary power.

In his analysis of power, Foucault takes five 'methodological precautions', which manoeuvre him into strict opposition to a political theory fixated on the sovereign or Leviathan and the legitimate order as well as on formal and direct, executive or legislative techniques of governing. His studies first follow power up to its furthest ramifications, even up to its capillaries, where it becomes paper-thin and less and less determined by law. The legal edifice of sovereignty and the system of individual rights fade thereby into the background.

Second, instead of the formal aspects of legal technology, Foucault examines the practices and techniques of power in order to grasp 'the material operations, forms of subjugation, and the connections among

\footnotetext{
69 Luhmann, 'Metamorphosen des Staates', 101, 108.

70 Foucault, Society must be Defended, 119, and Opitz, 'Zwischen Sicherheitsdispositiven und Securitization', 201, 208.
} 
and the uses made of the local systems of subjugation'. ${ }^{71}$ In this way, he dismisses one of the key problems that has preoccupied political theory and science, namely how, based on the diversity of individuals and efforts of will, a unitary will of the state or a single body politic can form and be given life by the 'soul of the sovereign' or constituted by the constitution, as was argued later. With this focus Foucault teases the illiberal governmentality out of the liberal paradigm and anticipates the shift of techniques of governing from direct regulations of behaviour to the screening of communication and the monitoring of movements and social processes by security and, as we learn these days, also by intelligence agencies.

Third, Foucault does not understand power as a monolithic, homogeneous phenomenon of rule, exercised in a linear fashion by command, but as something that circulates, works as a chain and is passed on to individuals and practised by them via networks. ${ }^{72}$ Thereby, he leaves behind the juridical conception of power as property and agency, which is the foundation for the methods Hobbes and Locke, and introduces the concept of relational power - a power which is expressed and valid in the relationships it is constituted by and whose exercise follows the laws of economics. ${ }^{73}$

Fourth, he does not derive power from a central authority but investigates it in an 'ascending analysis of power' ${ }^{74}$ starting from the micromechanisms that reveal to him the connections and uses of the local systems of subjugation. ${ }^{75}$ Finally and fifth, Foucault refrains from analysing the big power ideologies and, at least initially, also postpones an investigation of law. Instead, he focuses on dispositives and apparatuses of knowledge that emerge at the tapering ends of power networks and become effective as instruments for the accumulation of knowledge, methods of observation, techniques of recording and other more or less subtle mechanisms and practices. In the end he reveals the normative goal of his scientific method: in his lectures on governmentality and of Society Must Be Defended it becomes apparent that he wants to liberate

71 Foucault, Society Must Be Defended, 34.

72 The issues entailed in such a broad concept of power are discussed elsewhere in some detail. Cf. Honneth, The Critique of Power and Habermas, The Philosophical Discourse of Modernity, chs. IX and X.

73 Foucault, Society Must Be Defended and id., The Birth of Biopolitics, 144.

74 Foucault, Dispositive der Macht, 81 and id., Society Must Be Defended, 30.

75 Cf. Foucault, Madness and Civilization; id., Der Wille zum Wissen. 
'subjugated knowledge', whose historical substance was trapped and perished under the pressure of functional contexts and formal systematization.

The characteristics of the method Foucault as an established and practised political technology emerge (from Foucault's critical analyses and narratives) when emphasis is given to the strategies of indirect behavioural monitoring executed by the surveillance of events and spaces as well as the screening of communication. These strategies are embedded in the networks of disciplinary power and systems of control in regimes of illiberal governmentality.

Instead of a contractual Hobbesian arrangement covering the security of the territory and its borders or a liberal social contract geared towards the security of property and liberty, in Foucault's studies, at least in his later work, the state is empowered to intervene by a security contract of a different kind. Here we catch a puzzling glimpse of the state of exception defined neither in the traditional nor, as will be shown later, in a Schmittian manner:

[W] hen the normal course of everyday life is interrupted by an exceptional unique event, then the law is not sufficient. Then interventions are needed, which despite their extraordinary, extra-legal character ought not to appear arbitrary or an abuse of power, but as an expression of caring ... This ubiquitous care is the face that the state exposes to its citizens. ${ }^{76}$

The security paternalism diagnosed by Foucault curiously accommodates the aspect of care outlined in Locke's Elements of Law, modifies it and turns critically against it, in order to return to an analysis of law, whose concept is anchored in the liberal paradigm.

As is shown in the following chapters, the hyper-Orwellian security paternalism that characterizes the political technology of the method Foucault is enhanced by the erosion of structures and categories of law-rule aligned with a drastic reduction of judicial review. Dummy provisions, especially in police law and data protection law, signal the legislature's surrender to the new techniques of governing geared towards the accumulation and processing of data by intercepting communication, registering transactions, screening the internet, monitoring social events and processes, etc., which treat society as a production site for information and turn the state into an 'information-market state'.

76 Foucault, 'Die Sicherheit und der Staat', 140. See also Fitzpatrick and Golder, Foucault's Law. 


\subsection{POLITICAL TECHNOLOGY OF THE SECURITY STATE}

\section{Between the Negation and the Juridification of the State of Exception}

The function of the liberal-constitutional link between norm and legality is to exclude the arbitrary use of state power and to banish brute force from societal conflicts. Thus, the method Locke is accompanied by the naïve, or at least overly optimistic - idea that it erects a conceptual barrier that separates us from the places and times of savage violence. Unless the defence against unlawful state interference or civil rights violations has to be addressed, the liberal paradigm has considerable difficulty grasping and coping with exceptional situations even conceptually and including them in the framework of legislative political technology.

The theory and practice of Lockean governmental technology oscillate like a will-o'-the-wisp between two extremes. ${ }^{77}$ The optimistic version of the rule-of-law project is allowed by its rule rationalism to believe that normal law settles essential matters and any kind of arbitrary use of state power and any recourse to civil feud and law of the jungle are under control. In this way, political uprisings, coup attempts, wars or disasters are negated explicitly or implicitly. ${ }^{78}$ The state of exception does not occur; or rather it must not take place because its mere standardization would undermine the very normalcy the legal system refers to and relies on. Law-rule may focus on the management of normal situations. An emergency law does not exist; there remains only the prerogative as the power of promoting the public good, where law is silent, and discretion, where the law has no clear answer.

In contrast to the negation of the exceptional case, 'realistic' doctrines of law-rule interpret the rationalist project as the task of regulating all imaginable societal situations and conflicts and, therefore, also the unthinkable case of emergencies. They strive for the delicate 'registration

\footnotetext{
77 See, in particular, Chapters III and IV below.

78 Accordingly, Art. 13 of the French Constitution of 14 August 1830 prohibited the monarch from ever suspending the laws or preventing their implementation. Art. 130 of the 1831 Belgian Constitution states similarly: 'The Constitution can neither partly nor totally be suspended.' A comparable validity command can be found in Art. 108 Belgian Constitution.
} 
of the state of exception into the constitutional world'. ${ }^{79}$ Under the influence of legal positivism, ${ }^{80}$ many legal systems have tried, therefore, to juridify or legalize war, siege, civil war and disasters as exceptional cases, especially since the mid-19th century. In order to prevent extralegal measures, the manipulators of the method of political technology are given special powers for situations of extraordinary danger. The paradox of standardizing the extraordinary is meant to be overcome by tying the state of exception under emergency law or the rules on a constitutional dictatorship to a formal declaration, to rules of responsibility, deadlines, procedures and substantive objectives - largely according to the pattern of dealing with conflicts in normal situations. Of course, given the fact that these norms are geared towards their own elimination after the end of the state of exception, the paradoxical nature of this project becomes apparent.

\section{Normalizing the State of Exception}

The liberal dilemma in the face of extraordinary threats or extreme cases becomes apparent in its unsteady past. Various, early approaches to 'register' the state of exception 'into law-rule' were followed in totalitarian regimes, especially in National Socialism, by the practice of legal masking and perverting the exceptional case with the help of emergency decree law and the Nazis' infamous Enabling Act. After the Second World War, a first phase of resistance followed until emergency provisions - generally no longer related to a state of exception - were included in constitutions around the world. In many countries, the crises of law-rule ${ }^{81}$ that began in the 1980s under the banner of counterterrorism and were continued in the 1990s with the "war on terror and organized crime', revealed the risks and side effects of the positivist strategy of integrating emergency powers into the law of the normal state. The dynamics of 'registering' the state of exception as part of the norm,

79 Boldt, Rechtsstaat und Ausnahmezustand, 162. Typical in this context is the Act on the State of Exception of 4 June 1851, in Preußische GesetzesSammlung 1851, $451 \mathrm{ff}$.

80 In legal positivism, the state of exception 'formally lives the life of a general norm' as the epitome of the relevant rules under emergency law, which a legal order provides (Boldt, Rechtsstaat und Ausnahmezustand, 86 and 166 ff.).

81 I deal with the crises of the rule of law triggered by political terrorism in later chapters (Chapters 5, 6 and 7). 
which is to say the empirical and normative regularity in legal orders, ${ }^{82} \mathrm{I}$ characterize as a process of its gradual normalization. ${ }^{83}$ Normalization means that the instruments and ideology of emergency law are step by step wrapped in a cloak of regular normativity, are perpetuated and become part of everyday life through their juridification, their emergence as topoi under emergency law as well as their inclusion in the doctrines of regular law. In short: the exception is integrated into the norm.

The normalization of the extraordinary manifests itself at three levels of political technology. First, it becomes visible in a semantics camouflaging or trivializing deviance from democratic law-rule. Current examples are the demands of security policy-makers to allow the military to use 'military means' - in plain language, weapons - when they assist domestic authorities or use the armed forces domestically. In the same direction points the trivialization of torture, as 'life-saving forced statement', 'self-inflicted rescue questioning' or 'rescue torture'. This normalizing rhetoric and reasoning uses in each case a vocabulary that strips the respective phenomena of their exceptional nature in order to include them discreetly in the normalcy of the legal everyday. Incidentally, this vocabulary also opens the door for the systematic legal rehabilitation of the concept of the enemy.

Second, normalization also becomes apparent in a new legal topography. Boundaries and thresholds for intervention meant to safeguard freedom as well as categorical distinctions relevant for the authoritative 'invention' of citizens' duties are covered up by the new design of a security state. A clear indication of the normalization process are the structural distortions and 'materializations' of danger prevention law (police law) in the framework of a 'new security architecture', ${ }^{84}$ which will later be shown to shift from cognitive to (pseudo-)existential security. Within the framework of this architecture, the categorical differences between peacebreaker and peaceful citizen, between danger and risk are eliminated, and danger prevention law is transformed into a 'danger invention law'. Similarly, 'probable cause' loses more of its already endangered protective function in criminal law enforcement. Within the overall new topography of the security state, the protection of persons by guaranteeing the certainty of law falls prey to an illusory

82 For a slightly different definition, see Ferejohn and Pasquino, 'The Law of the Exception', 221.

83 Regarding the argument that the state of exception becomes normalized and an everyday phenomenon, see Frankenberg, 'Kritik des Bekämpfungsrechts' and Dyzenhaus, 'The Permanence of the Temporary'.

84 See Burwell et al., Transatlantic Transformation. 
certainty with regard to the objects protected by law (Rechtsgüter). In turn certain 'dangerous elements', types of perpetrators and even suspects are excluded from legal protection and thus are relegated, if so required by necessity, to the status of enemies.

Third, this normalization process becomes functionally manifest in norms which inscribe new tasks and competences into the topography of law, in particular into danger prevention law and criminal codes. In functional terms the characteristics of this 'new security architecture' are (a) the extension of the agenda of counter-terrorism; its areas of threat comprise international terrorist networks, the proliferation of weapons of mass destruction, and human trafficking; 85 (b) data sharing and cooperation between police, security agencies and intelligence services as the inner structure of the surveillance state; (c) efforts to extend the domestic use of the armed forces; (d) the screening of online and offline communication, video-surveillance of public areas, wiretapping, and the registration of economic transactions; and last but not least, (e) the dramatic advance and institutional increase of cyber-espionage. ${ }^{86}$ While the 'new security architecture' comprises strategies to control cyberspace, this does not mean that it abandons physically coercive measures. Attempts to normalize torture will be analysed in detail below; along with doctrines designed to legitimize the downing of so-called renegade aircraft. 87

\section{Political Technology as Security Technology}

Normalizing the state of exception begins within law-rule whenever discretionary power is set free from legal restraints and therefore the application of a norm in single cases can scarcely be anticipated. The normalization becomes more general with the integration of extraordinary measures into the standard texture of law-rule. ${ }^{88}$ Ultimately, the normalizing dynamics submit the rationality of law-rule to the imperatives of the security state. This process and dynamics follow a specific security script: the conventional law-rule prevention of danger gives way to the logic of hyper-prevention. Governmental (police) operations encompass not only concrete threats but also potential, abstract risks and therefore extend spatially far beyond zones of danger and temporally into the future. Hyper-prevention requires that the police are at the scene of

\footnotetext{
85 Frankfurter Allgemeine Sonntagszeitung, 16 June 2013, p. 7.

86 Schirrmacher, 'Der verwettete Mensch'; Bobbitt, Terror and Consent.

87 See Chapters 4 and 6 (downing of renegade aircraft) and 7 (torture).

88 See Chapters 5 and 6.
} 
the crime before the offender, that the engineers of security know what we will do tomorrow, and that they are largely exempt from legal molestations in order to allow them to operate smoothly in whatever "war on ...' they are fighting.

The security state has become a global phenomenon ${ }^{89}$ and manifests, as was argued and will be shown, a new logic of political technology. Driven by dramatic, anxiety-inducing threat scenarios, like the image of the 'ticking bomb' or the pervasive metaphor of war, the Hobbesian question has directed attention to how a citizenry can be monitored and their energies curbed by government in order to effectively prevent as early as possible excess activities of civil society and, in particular, the criminal activity of 'dangerous elements' - 'organized crime' and terrorists. The Hobbesian scenario has been modernized though: political technicians' operations follow the logic of the undeclared state of exception and the assumption that threats emerge primarily out of the middle of society, emanating not only from 'sleepers', 'dangerous elements' and other incarnations of 'evil' but also from those who do not deviate from what is considered normal behaviour. Therefore, society has to be kept under constant monitoring, screening and surveillance. 'Securitization' in a regime of illiberal governmentality is called for. In this regime the normalized state of exception turns out to be the twin brother of law-rule, which may explain the 'striking fact that, even in those advanced democracies whose constitutions contain provisions for emergency powers, these powers are not used'. ${ }^{90}$ Why openly use them when they can be discreetly integrated into the texture of law-rule?

89 For the vast literature on the security state, see e.g. Balkin, 'The Constitution in the National Surveillance State'; Darnstädt, Der globale Polizeistaat; Klinsman et al., Whose National Security?; Kirshner, Globalization and National Security; Lewis, Globalization and National Security.

90 Ferejohn and Pasquino, 'The Law of the Exception'. 